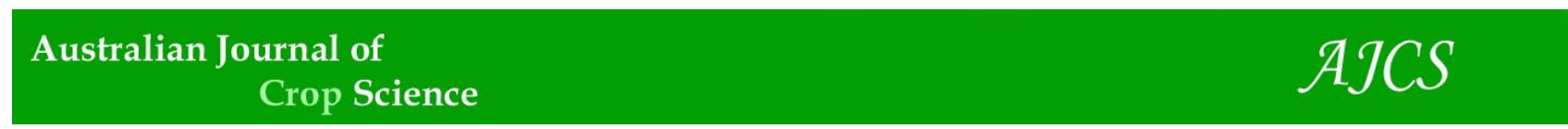

AJCS 11(09):1161-1167 (2017)

ISSN:1835-2707

doi: 10.21475/ajcs.17.11.09.pne454

\title{
Crop-livestock integration under no-tillage: genuine Brazilian technology with economic and environmental sustainability: A review
}

\author{
Alyne Dantas Mendes de Paula ${ }^{1}$, Diego Tolentino de Lima ${ }^{1}$, José Luiz Rodrigues Torres ${ }^{2}$, Gabrielly \\ Isaac Rodrigues ${ }^{1}$, Ernane Miranda Lemes ${ }^{1}$ \\ ${ }^{1}$ Agronomist, Graduate Program in Agronomy, Institute of Agricultural Sciences at the Federal University of \\ Uberlândia. Av. Amazonas s/no, Umuarama. Uberlândia-MG, Brazil. Zip code: 38400-902. \\ ${ }^{2}$ Plant Production, Federal Institute of Mining Triangle (IFTM) - Uberaba Campus, MG, Brazil. Rua João \\ Batista Ribeiro, 4000. Uberaba-MG, Brazil. Zip code: 38064-790.
}

*Corresponding author: jlrtorres@iftm.edu.br

\begin{abstract}
Crop-Livestock Integration System (CLIS) under no-tillage system (NTS) is a technology that has proven critical to the maintenance of agricultural and environmental sustainability in Brazilian tropical conditions. It is one of the alternatives developed by national research for producers to optimize and diversify the use of agricultural areas to obtain higher incomes by area with lower costs, besides recovering degraded areas and improve the physical, chemical and biological soil. The aim of this review is to disseminate results and gather information to demonstrate that CLIS under NTS is a Brazilian technology with economic and environmental sustainability is applicable to several regions. It was observed that the use of CLIS with NTS in our tropical climate conditions is an important tool that provides food production (grains), meat and milk with sustainability in most regions.
\end{abstract}

Keywords: sustainable management, crop rotation, soil quality.

Abbreviations: $\mathrm{AD}_{-}$Available Water; $\mathrm{CH}_{-}$Hydraulic Conductivity; DAP _ Bulk Density; DMP _ Average Diameter; DS _ Soil Density; IFS _ Water Infiltration into the Soil; MA _ Macroporosity; MI _ Microporosity; PR _ Soil Resistance to Penetration; PT _ Total Porosity; UV - Volumetric Water Content; CLIS _ Crop-Livestock Integration System; NTS _ No-tillage system; CTS _ Conventional Tillage System; GHG__ Greenhouse gases; MHa _ Million hectares.

Introduction

Increased global demand for food has urged for new technologies and sustainable production systems in Brazil and in the world to be developed, for higher yield, without increasing production costs and opening new areas for agricultural exploration. According to Macedo (2009) the intensive use of the soil in farming and conventional farming under continuous tillage with successive harrowing and degradation of pastures are the most outstanding aspects related to sustainability of agricultural production. Important technologies have been used to alter the unsustainability frames of production in these areas among which are the adoption of no-tillage system (NTS) in the traditionally grainproducing areas, and crop-livestock integration system (CLIS) in meat and milk. While no-tillage system (NTS) is a conservative management farming, which is based on no soil disturbance, and also helps fight erosion, increases the carbon and nitrogen stocks in the soil profile, especially when associated with the rotation of annual crops (Allen et al., 2008), the CLIS aims at sustainability of long-term production systems, with a view to the proper management of available resources. Both systems (NTS and CLIS) are based on crop rotation. In Cerrado, Loss et al. (2011) emphasize that depending on the climate and temperature, the decomposition rate of the straw is accelerated, the soil being quickly uncovered, these factors promote a less efficient NTS if compared to the decomposition that occurs in other biomass. This way, CLIS is fundamental because its use associated with Poaceae species enhances the production of straw with lower rates of decomposition, especially during the dry season. When CLIS is carried out under NTS with crop-pasture rotation i.e. the combination of agriculture cycles with livestock cycles in succession in the same area that support the rotation of annual crops of grains with annual or perennial pastures (Carvalho et al., 2006), it is possible to reduce the use of chemicals once the cycle of pests and diseases is disrupted, property net income is increased. Also, jobs creation and maintenance of families in rural areas, providing economic, social and environmental benefits, giving it the title of highly sustainable system (Herrero et al., 2010). Despite the existence of studies on the CLIS carried out under NTS in some regions of the country, in others it is scarce. This literature review aims to disseminate results and gather information to demonstrate that the CLIS carried out under NTS is a Brazilian technology with economic and environmental sustainability, applicable to several Brazilian regions.

\section{Results and discussion}

Traditional crop-livestock integration system (CLIS)

Conceptually the crop-livestock integration system (CLIS) stand for production systems that integrate agricultural activities and livestock in a synergic and systemic way, 
whose basic premise rationally maximize land use in time and space, diversifying and elevating agricultural production, minimizing costs, and diluting risks through the benefits that an activity provides (Vilela et al., 2011).

The CLIS consists on the implementation of different production systems of grains, fiber, meat, milk, bioenergy, among others, in the same area, in intercropping, sequential or rotational planting (Macedo, 2009). The use of forage species, interspersed with annual and pasture crops creates an integrated production system, naturally called crop-livestock integration system (CLIS) (Loss et al., 2011).

According to Balbinot Junior et al. (2009) CLIS can be successfully used in small and large farms in any region of the country, once it is a production system that switches in the same area, the cultivation of annual or perennial pastures for animal production, and crop production, especially grains. In Cerrado, which covers several regions of the country, the agriculture exploitation has been intensified since the $70 \mathrm{~s}$, initially with rice cultivation, once cattle was still rudimentary and was based on native pastures, which only came develops from the next decade. According Kluthcouski and Aidar (2003), in the 80s the discussion about the sustainability of agricultural production and aspects such as land use in conventional agriculture and degradation of pastures took important role among producers, researchers and society involved in food production. The traditional and conservation practices of preparation with soil disturbance that generate soil and natural resources degradation were then replaced by more sustainable forms of production.

In the 90s the Barreirão system has emerged as a precursor alternative to the restoration / renovation of degraded pastures, in order to reduce the cost of these actions, where plantations of commercial crops and forage plants were carried out simultaneously with the intention to reduce climatic risks and correct soil physical properties (Macedo, 2009).

One of the main objectives of this practice is the partial or total coverage of the recovery costs of grazing with grain production. The set of recommended techniques is based on interdependent steps and sequential, which if properly applied will result in reform of the pasture and in simultaneous production of grains, beyond recovery physicalchemical characteristics of the soil (Kluthcouski et al., 1991). The adequate preparation of the soil for the implementation of the Barreirão system aims to achieve three basic objectives, which are the incorporation of organic and corrective waste, soil decompression and control of invasive plants. It is initially done a harrowing take in the area, which will facilitate a subsequent plowing deep, with this will decrease the need of operations of tillage and leveling the ground, especially if it is used the moldboard plow (Macedo, 2009).

A short time later Santa Fé System started working based on the consortium production of grain crops, especially maize, sorghum, millet and soybeans with tropical forages, especially the genus Urochloa sp. both in no-tillage and in the conventional one in crop areas, with appropriately corrected soil (Kluthcouski et al., 2000; Viana et al., 2007).

The main objectives of this system are the production of fodder for the off season, production of straw in quantity and quality for no-tillage system (NTS) in the next harvest (Kluthcouski and Aidar, 2003) and, obviously, grain production, one of the most innovative aspects being The application of the concepts of crop-livestock integration with the NTS.
According to Cobucci et al. (2007) Santa Fé System is the consortium production of annual crops with tropical forages, the main crops used in the system being maize, millet, sorghum, rice, soybean and sunflower, among others. Among the forage plants Brachiaria plays a major role. In Luziânia, $\mathrm{GO}$, the Santa Fe System was implemented in areas irrigated by center pivot and forage production, with supplementary irrigation, which fed eight ha $^{-1}$ animal with weight gain estimate of about $800 \mathrm{~g} \mathrm{Animal}^{-1} \mathrm{day}^{-1}$.

However, much of the non-compliance in the adoption of the system is the uncertainty of the relative productivity of mixed and single crops. This doubt among farmers is common and makes sense, since in poorly designed and conducted systems there might be high competition between forage plants and annual crops, thus, reducing the productivity of the latter ones (Borghi and Crusciol, 2007). However, management strategies that enable no competition between forage and culture are needed, thus ensuring crop yields. Aspects such as depth of forage seeding, line spacing, time delay in sowing of the crop for forage and harvest at the appropriate time

One of the alternatives to avoid the competition between the annual crop and the forage crop is to sow the forage in depth at a greater depth than the crop, at the time of simultaneous sowing, taking care that this depth does not compromise the forage emergence (Silva et al., 2011). In the Santa $\mathrm{Fe}$ system, high quality straw can be produced, with a production of more than $15 \mathrm{Mg} \mathrm{ha}^{-1}$ of dry biomass, when well managed, and persisting for a long period at the soil surface (Mantovani et al., 2015).

\section{Choice and consortium viability in crop-livestock integration systems}

The from the Santa Fé system was implemented the integrated crop-livestock system (CLIS), providing high economic return and production potential of milk and meat, which have been shown in several studies. Carvalho et al. (2014) found that the CLIS allows greater flexibility in the degree of intensification in the production of the pasture milk, since it implies the diversification of funding sources. Besides, it reduces production risks and negative environmental impacts as well.

This system aims at the diversification of land use, based on the spatial and temporal integration of the components of the productive system, causing a reduction in the pressure on the natural ecosystems (Salton et al., 2014; Cordeiro et al., 2015; Vilela et al., 2015), which has become an excellent tool to achieve the synergy between agricultural production and environmental quality in the Cerrado biome.

In relation to land use in the Brazilian Cerrado, Loss et al. (2016) report that until the $70 \mathrm{~s}$, the main land use was extensive grazing, then these areas were converted into annual crops with conventional tillage system (CTS) through plowing and harrowing. Later, with the emergence of conservation practices, the CTS was replaced by the notillage system (NTS) and more recently part of the NTS was converted to CLIS.

One of the most important steps in the CLIS is the choice of species because several are cultures that have been used in this system, among them corn, wheat, sorghum, soybeans and millet, as well consort with forage grasses (Santos et al., 2013). In general the consortium between maize and fodder is 
Table 1. Effects of Integrated Crop-Livestock under no-tillage system.

\begin{tabular}{llll}
\hline Author (s) & $\begin{array}{l}\text { Soil } \\
\text { attributes }\end{array}$ & Treatments & Results \\
\hline Sales et al. (2010) & MA, MI, DS, CH & $\begin{array}{l}\text { Continuous grazing, NTS with soy } \\
\text { or corn, soy CLIS (harvest) and } \\
\text { corn (off-season) and cerrado. }\end{array}$ & $\begin{array}{l}\text { Change compared to native vegetation, but } \\
\text { not between CLIS and NTS. Changes not } \\
\text { considered critical for plants root } \\
\text { development. }\end{array}$ \\
Marchão et al. . (2007) & $\begin{array}{l}\text { DS, UV, RP, } \\
\text { MA, MI, PT, AD }\end{array}$ & $\begin{array}{l}\text { Pasture or continuous crop, CLIS } \\
\text { with NTS or PC and native Cerrado }\end{array}$ & $\begin{array}{l}\text { Increments in RP and DS on all systems } \\
\text { compared to the native vegetation. } \\
\text { Compacting by animal trampling did not } \\
\text { reach critical values, limiting subsequent } \\
\text { annual crops. }\end{array}$ \\
Bertol et al. (1998) & IFS, PT, DMP, & $\begin{array}{l}\text { Forage allowance levels (4, 8, 12 } \\
\text { and 16\%) in a natural pasture. }\end{array}$ & $\begin{array}{l}\text { With lower supply of forage (4 and 8\%). } \\
\text { Reduces the rate of IFS, PT and DMP of } \\
\text { aggregates and increase in DAP. }\end{array}$ \\
Dlores et al. (2007) & DS, MA, MI, PT & $\begin{array}{l}\text { Pasture management heights (no } \\
\text { pasture, 0.10, 0.20, 0.30, and 0.40 } \\
\text { m). }\end{array}$ & $\begin{array}{l}\text { Changes by animal trampling did not } \\
\text { reach harmful levels when the soybean } \\
\text { crop in a post grazing, but DS was higher } \\
\text { and PT lower in grazed areas. }\end{array}$ \\
\hline MA = macroporosity; MI = microporosity; PT = total porosity; PR soil resistance to penetration; DS = soil density; CH = hydraulic conductivity; UV volumetric water
\end{tabular}
content; $\mathrm{AD}=$ available water; $\mathrm{IFS}=$ water infiltration into the soil; $\mathrm{DMP}=$ average diameter; $\mathrm{DAP}=$ bulk density.

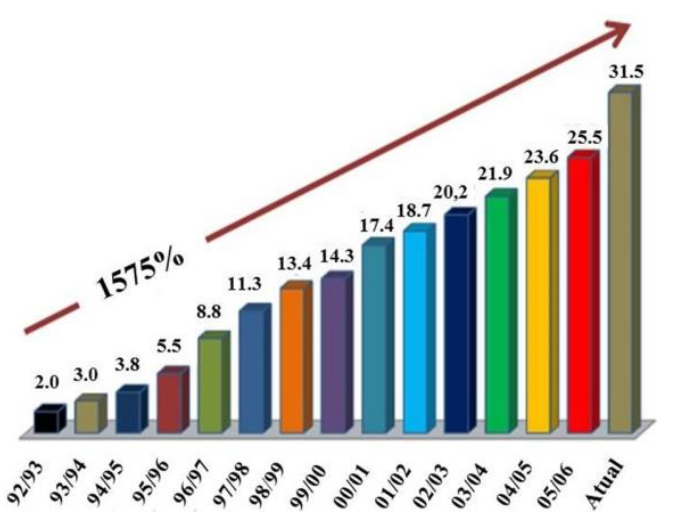

Fig 1. Development of NTS in Brazil. Sources: Febrapdp (2012); Conab (2004; 2008; 2012).

established annually and productivity of corn grain is not being affected (Mendonça et al., 2014). In the Brazilian Cerrado it is very common to grow maize intercropped with Brachiaria, which are sown simultaneously and after maize harvest, the introduction of cattle in the area is carried out, with the animals staying for 3 to 4 months. After the withdrawal of the cattle, when the rains begin in the Cerrado, a fertilization is carried out in a cover in the brachiaria. After the regrowth, when the area is completely covered by the weeding, the straw is desiccated and the planting of the summer crop, such as beans, cotton or soybean (Loss et al., 2012). Some typical characteristics of corn allow its use in intercropping systems, such as high plant size and rapid initial development that favors forage shading, the insertion point of the reproductive organ (of economic interest), the rate of accumulation of dry matter, the availability of selective post-emergence herbicides and the possibility of reducing the spacing between the planting rows (Balbinot Junior et al., 2009). Another interesting point of corn is that the forage seeding time is indifferent in crop production responses. Garcia et al. (2012) studied the cultivation of corn intercropped with forages simultaneously sown. At the time of nitrogen topdressing, they found no reduction in grain yield in corn grown without the consortium. However, the consortium of corn grown with Urochloa ruziziensis showed higher rate profitability. Besides ensuring livestock production, in CLIS forage plants act: a) As recyclers of nutrients after the annual crop (Krutzmann et al., 2013); b) In the physical structure (Mendonça et al., 2014); c) Input of organic matter in the soil; d) In the production of straw to the NT (Carvalho et al., 2014). They also contribute to weed management (Gimenes et al., 2011), preserving the productivity of annual crops, reducing production costs and generating monthly or annual revenue. In maize, it is interesting growing other crops, since the greater the diversity of crops and genres involved, the greater the biodiversity and the potential for biological control of diseases, pests and weeds. Santos et al. (2013) have evaluated the cultivation of soybeans and wheat after ten years of introduction of multiple production systems with CLIS, involving other crops and forage maize, black oats, peas, triticale, vetch, white oats, white and red clover, birdsfoot, trefoil, Pensacola, ryegrass and alfalfa, not observing a difference in the yield of soy beans, while for wheat must- to seek appropriate recommendations to obtain the highest yield. In addition to fix nitrogen, soybeans have plant height and first pod insertion consistent with mechanized harvesting, with no loss in harvest. The straw of forage plants intercropped with corn does not interfere with soybean yield in succession, if compared to single corn and soybeans crop (Mendonça et al., 2014). For the best use of the area and better results in cropLivestock Integration, the forage component should consist of species that have good growth, good tillering capacity, high nutritional value, and especially that are adapted to the conditions of moderate shading. However, when forage plants are broadcast seed on soybeans at R7 stage or soon 
after harvesting the crop, if those forages are managed at the height of $0.30 \mathrm{~m}$ with cattle grazing, when deploying a new soybean crop at the next harvest, yield components and soybean yield are not influenced by vegetation cover when forage plants such as Urochloa ruziziensis and Urochloa brizantha are intercropped with Tanzania grass (Krutzmann et al., 2013).

\section{Tropical pastures and their degradation process}

The current stage of degradation of pastures in the country undermines the sustainability of livestock, especially beef cattle and milk, which is still carried out mainly in pastures, and may explain the dynamic process of degeneration or relative productivity falling.

Among the most important factors related to the degradation of pastures we can highlight inadequate animal management and the lack of spare nutrients as excessive animal stocking without adjustments for proper bearing capacity, and lack of maintenance in fertilization have been the accelerators of the degradation process (Macedo and Zimmer, 2007). The authors emphasize that extensive farming systems still predominate over the other, and pastures used can be native or cultivated, where grasses belonging to the genera Urochloa sp., Panicum and Andropogon are predominant. Cerrado is estimated to have 49.5 million hectares of cultivated pasture, a total area of 208 million hectares, which account for about $50 \%$ of the country's meat production.

Another concern is about the soil physical properties, because the cattle presence may cause modification of these attributes due to trampling. Several experiments conducted over the past decades have found how different agricultural management systems, encompassing both annual crops and forage ones have influenced these attributes. This influence is directly linked to management adopted in the area (Table 1). Evaluating the effect of grazing pressure on soil physical properties and yield of two soybean cultivars 'BRS 255RR' and 'BRS 294RR' in CLIS with Urochloa brizantha, Debiasi and Franchini (2012) observed critical changes to the culture in depth $0.00-0.05 \mathrm{~m}$, concluded that the productivity of one of the cultivars was not affected by grazing pressure and desiccation times of forage plants. However, the increased productivity of cultivar 'BRS 294RR' was obtained in the area with higher grazing pressure, which indicates that most soil compaction due to animal trampling did not reduced the soybean yield.

While studying the effect of corn intercropped with four forage plants Mendonca et al. (2014) observed that the succession corn and soybean resulted in improvement in physical attributes at depths $0.0-0.10,0.10-0.20$ and 0.20 $0.30 \mathrm{~m}$, an increase of macroporosity, total porosity and reduction in soil density, regardless of the forage plant intercropped with corn, and sowing methods as well.

Evaluating the effect of different heights of grazing on soil physical properties, after seven years under CLIS, Moreira et al. (2014) found that the intensification of grazing changed the density, macroporosity, total soil porosity, in addition to changing the aeration capacity of the soil matrix, and water/air storage. That was the smallest grazing height $(0.07$ $\mathrm{m})$, reducer of the soil physical quality in depth of 0.00 $0.15 \mathrm{~m}$, while the remaining grazing heights $(0.14,0.21$ and $0.28 \mathrm{~m}$ ) and ungrazed witness do not interfere with the soil physical quality.

\section{Integrating no-tillage system and farming crop}

The no-till system (NTS) on straw was introduced in southern Brazil as a conservationist technology in the late 1960s, with technological levels and systems adapted to the different regions. It gradually expanded to all regions of the country, reaching 1.0 million hectares in the 1989/90 harvest. From that crop, growth was exponential culminating with 31.5 million hectares (31.5 MHa) in the 2011/2012 harvest (Febradp, 2012) and projected to reach 33 million hectares (33.0 MHa) in 2020 (Figure 1) (Mapa, 2012).

The sustainability of the agricultural sector should be directly related to the evolution of the production system, as NTS and CLIS are principles of management of the conservationist soil. Macedo (2009) It notes that the reversal of unsustainable production has been observed from the use of these technologies, which include non-soil disturbance, but also the practice of crop rotation, and integration between systems.

With the mastery of techniques that make up the NT in the tropical region, with the possibilities of producing large quantities of plant residues through cover crops, it is possible to build systems of sustainable production, with environmental, economic, social, and agronomic benefits. Such systems contribute to the maintenance of humidity, temperature and organic matter that benefit soil flora and fauna, as well as improve physical, chemical and biological attributes (Kluthcouski and Aidar, 2003).

Some studies have shown that increased production of green biomass in grazing areas acts as a mattress, and cushions the animal trampling. Flores et al. (2007), Marchão et al. (2007), Salton et al. (2008) and Debiasi and Franchini (2012) have reported that cattle trampling on the soil is potentiated when grazing is carried out in soils with high humidity and low vegetation, and that highlights the need to maintain adequate vegetation cover on soil in order to mitigate this effect on the soil quality.

\section{The crop-livestock integration system (CLIS) under no- tillage system (NT)}

The CLIS conducted under NT is a Brazilian technology, which introduces the structural conservation, maintenance or increase in the content of organic matter $(\mathrm{OM})$, improvement of the physical, chemical and biological soil attributes, which are enhanced by the introduction of forage species in rotation, that generally accumulate more carbon than agricultural crops (Carvalho et al., 2006).

The CLIS under NT results in a system where the benefits, such as maintenance of soil aggregation and increased levels of $\mathrm{OM}$, associated with crop rotation, create a more diverse environment if compared to an area under NT alone (Loss et al., 2011).

The rotation between annual and forage crops, and the presence of the animal grazing in cycles between cultures, brings a diversity component that is not achieved only with NT. That association changes the dynamics of nutrient cycling in the system, benefiting the culture in succession when the grazing intensity is properly handled, therefore, this system has been used as a means for the recovery of degraded pastures by promoting improvements in productivity through intensification of land use, and decreasing the removal of native vegetation (Salton et al., 2008). 


\section{Physical, chemical and biological soils}

Several experiments conducted over the past decades have found how different agricultural management systems, encompassing both annual crops and foragers have influenced the physical soil properties. Assessing the stability of aggregates (SA), light organic matter (LOM) and the contents of total soil organic carbon (SOC) under NT with CLIS, NTS without CLIS, and an area of natural Cerrado, Loss et al. (2011) have observed that the area of Cerrado showed the best aggregate stability indexes in the $0.05-0.10 \mathrm{~m}$ layer. CLIS under NT showed better SA indexes, LOM and total SOC content in the layer of 0.00-0.5 and 0.05-0.10 m, better than in CLIS without NT. While studying the effect of different CLIS production systems on fertility of the soil under NT, Santos et al. (2009) have found that the soil layers from 0.00-0.05 and 0.05-0.10 m increased levels of organic matter, $\mathrm{P}$ and $\mathrm{K}$, while $\mathrm{Al}$ and $\mathrm{pH}$ values decreased. Furthermore, the management systems studied caused greater accumulation of SOC than in the subtropical forest and cycled more nutrients that would be lost by lixiviation.

While analyzing soil management systems with crop and pasture rotation (Urochloa brizantha) under NTS, Salton et al. (2008) observed that this system favors the formation of stable aggregates of larger size, if compared to crop systems. They justify that, with higher moisture uniformity, these areas have better root development of crops, thus creating a more favorable environment to soil aggregation. Moreover, the perennial pasture have large effect on aggregation rhizosphere, because they have higher density of roots and better distribution of the root system in the soil, thus favoring the links of contact points among mineral particles and aggregates.

The CLIS under NTS cause improvement in soil quality, since it can increase the organic carbon concentrations in the soil over time, due to the continuous growth of plants in the area, whether pasture or crops for plant operation, crop rotation, increase in mass produced by time due to grazing, or higher nutrient cycling.

While studying the grazing intensity ratio with the stock of organic carbon and nitrogen in soil with CLIS under NT, Souza et al. (2009) have found that moderate grazing intensities ( 0.20 and $0.40 \mathrm{~m}$ high pasture) promoted an increase in the total $\mathrm{CO}$ inventory, particulate $\mathrm{CO}$, total $\mathrm{N}$ and $\mathrm{N}$ in particulate organic matter in the soil, similarly to NT without grazing, i.e., adopting the optimal management of CLIS and adequate grazing intensities, besides promoting numerous benefits, carbon can be stocked, thus reducing the negative effects in the atmosphere. In well-managed pastures and in areas where there was the conversion of native vegetation into agricultural areas, in general, carbon accumulation is observed (Carvalho et al., 2009). However, carbon losses are observed in degraded pastures (Maia et al., 2010). The differences in the results can be attributed to differences in soil type, type of forage plants, management practices (CLIS, NT or conventional tillage), crop rotation, weather conditions and intensity of cultivation practices. The increase in soil carbon, resulting from increased soil organic matter (SOM) content has been considered one of the best environmental indicators to assess the changes caused by the use of conservationist tillage systems in production areas as it directly influence the quality of the soil (Loss et al., 2011).

\section{Carbon sequestration and the greenhouse effect}

Gases of the "Greenhouse Effect" (GHG) from human activities have increased considerably, which in consequence, may cause a global temperature increase estimated between 2 and $6{ }^{\circ} \mathrm{C}$ by the year 2100 (IPCC, 2014). According to Galford et al. (2013) due to the increase in world population and the use of fossil fuels, the concentration of $\mathrm{CO}_{2}$ in the atmosphere has increased from 280 to $380 \mathrm{ppm}$. The major anthropogenic sources of $\mathrm{CO}_{2}$ emissions come from the burning of fossil fuels and biomass, as well as mineralization of soil SOM. The conversion of native vegetation in agricultural systems results in significant emissions of $\mathrm{CO}_{2}$ and other GHG in the atmosphere.

The main strategies for reducing the emission of GHGs consist of: reduction of the burning of fossil fuels; minimization of deforestation and fires, management of agricultural systems with responsible and sustainable land use, and maximization of carbon sequestration in the soil. As for the last two strategies, the use of soil conservation is indisputable for its optimization (Carvalho et al., 2009). The conversion of 12 million hectares $(\mathrm{MH})$ of conventional tillage to NT until 2020 may represent a removal of $138.5 \mathrm{Mg}$ $\mathrm{CO}_{2}$-equivalent from the atmosphere, in a more optimistic scenario $24 \mathrm{MH}$ removal of $277.1 \mathrm{Mg} \mathrm{CO}_{2}$-equivalent (Cerri et al., 2010).

On the other hand, the conversion of Cerrado vegetation in agricultural systems may cause different results for storage of organic carbon, depending on soil management practices (Maia et al., 2010), which reflect the degree of productivity or pasture degradation. The CLIS may cause a reduction in $\mathrm{CO}_{2}$ emissions to the atmosphere, as it aims: to increase the amount of biomass produced for NT and cattle food and; at associating good soil fertility levels of crops under NT with high pastureland capacity to increase the stock of organic carbon. It is likely to occur an increase in carbon stocks in the soil (Carvalho et al., 2010).

When assessing the changes in carbon stocks and fluxes of GHG (expressed in $\mathrm{CO}_{2}$-equivalent) in soils of Brazilian Cerrado, Carvalho et al. (2014) have quantified the GHG balance after conversion of native vegetation into pastures and agricultural areas, and the conversion of agricultural areas into CLIS. They have observed that the conversion of native vegetation for grazing and agriculture decreased the stocks of organic carbon, with rates losses ranging from 0.25 to $0.64 \mathrm{Mg} \mathrm{C} \mathrm{ha} \mathrm{yr}^{-1}$, respectively. The CLIS use in agricultural areas increased organic $\mathrm{C}$ stocks at $0.60 \mathrm{Mg} \mathrm{ha}^{-1}$ $\mathrm{yr}^{-1}$.

Those authors have reported that the net emission of soil greenhouse, including all greenhouse gases expressed in $\mathrm{CO}_{2}$ equivalent, has indicated that the conversion of native vegetation into pastures and agricultural areas has resulted in emissions of 0.54 and $0.72 \mathrm{MgC} \mathrm{ha}^{-1} \mathrm{yr}^{-1}$, respectively. Moreover, CLIS adoption in areas under cultures succession was of $0.36 \mathrm{Mg} \mathrm{ha}^{-1} \mathrm{yr}^{-1}$. The authors have demonstrated that the introduction of CLIS has proved to be a good strategy to reduce GHG emissions from the soil in the Brazilian Cerrado.

\section{Conclusion}

Among the advantages observed with use of CLIS under NT involving agriculture and livestock one can highlight: a) the partial or total faster return of the capital invested; b) the recovery of degraded pastures; c) the production of forage pastures in quantity and quality; d) the improvement of physical, chemical and biological soils; e) the increasing of carbon stocks in the soil; f) the reduction of greenhouse gases; g) the vertical integration of agricultural production; $h$ ) the reduction of deforestation pressure in the areas of expansion of the agricultural frontier, among others, which enable the production on farms with sustainability. 
On the other hand, in order to obtain all the advantages of this system it is necessary to take into account various aspects such as: a) the viability of the consortium of forages and annual crops linked to the interests of the production systems in use; b) the ideal choice of species in CLIS and how their productivity can be affected; c) proper management of grazing and how it can influence the physical and chemical soil, concerned with compression; d) knowledge of the interaction among plants, animals and soil, and how weeds interfere with this system; d) the realization of nutrient cycling through this integration and how soil fertility can be altered by it; e) carbon sequestration that can occur by increasing the content of soil organic matter, besides all planning of actions to be developed on the property.

Thus, CLIS is an important tool for agricultural sustainability in the Brazilian Cerrado. However, further research needs to be developed in the area, so that the study of forage species integrated to annual crops is deepened, as well as the study of the characteristics of soil and climate of the region and how these factors can interfere with the system as a whole.

\section{Aknoledgements}

The authors thank the Federal Institute of Triângulo Mineiro (IFTM) - Uberaba Campus, MG, Brazil , for the infrastructure concede; the Research Supporting Foundation for the State of Minas Gerais (FAPEMIG), Coordination for the Improvement of Higher Education Personnel (CAPES) and the National Council of Scientific and Technological Development $(\mathrm{CNPq})$ for funding the project and granting scholarship.

\section{References}

Allen VG, Brown CP, Segarra E, Green CJ, Wheeler TA, Acosta-Martinez V, Zobeck TM (2008) In search of sustainable agricultural systems for the llano estacado of the US southern high plains. Agr Eco Env. 124: 3-12.

Balbinot Junior AA, Moraes A, Veiga M, Pelissari A, Dieckow J (2009) Integração lavoura-pecuária: intensificação de uso de áreas agrícolas. Ci Rur. 39: 19251933.

Bertol I, Gomes KE, Denardin RBN, Machado LAZ, Maraschin GE (1998) Propriedades físicas do solo relacionadas a diferentes níveis de oferta de forragem numa pastagem natural. P Agr Bras. 33: 779-786.

Borghi E, Crusciol CAC (2007) Produtividade de milho, espaçamento e modalidade de consorciação com Brachiaria brizantha em sistema de plantio direto. P Agr Bras. 42: 163-171.

Carvalho JLN, Cerri CEP, Feigl BJ, Píccolo MC, Godinho VP, Cerri CC (2009) Carbon sequestration in agricultural soils in the cerrado region of the Brazilian Amazon. Soi Til Res. 103: 342-349.

Carvalho JLN, Raucci GS, Cerri CEP, Bernoux M, Feigl BJ, Wruck FJ, Cerri CC (2010) Impact of pasture, agriculture and crop-livestock systems on soil $\mathrm{C}$ stocks in Brazil. Soi Til Res. 110: 175-186.

Carvalho JLN, Raucci GS, Frazão LA, Cerri CEP, Bernoux M, Cerri CC (2014) Crop-pasture rotation: A strategy to reduce soil greenhouse gas emissions in the Brazilian Cerrado. Agr Eco Env. 183: 167-175.

Carvalho PCF, Moraes A, Anghinoni I, Lang CR, Silva J LS, Sulc RM, Tracy B (2006) Manejo da integração lavoura/pecuária para a região de clima subtropical. In: Encontro Nacional de Plantio Direto na Palha, 2006,
Uberaba - MG. Integrando Agricultura, Pecuária e Meio Ambiente. FEBRAPD, 2006. p.177 - 184.

Cerri CC, Bernoux M, Maia SMF, Cerri CEP, Costa Junior C, Feigl BJ, Frazão LA, Mello FFC, Galdos MV, Moreira CS, Carvalho JLN (2007) Greenhouse gas mitigation options in Brazil for land-use change, livestock and agriculture. Sci Agr. 67: 102-116.

Cobucci T, Wruch FJ, Kluthcouski J, Muniz LC, Martha Junior GB, Carnevalli RA, Teixeira SR, Machado AP, Teixeira Neto ML (2007) Opções de integração lavourapecuária e alguns de seus aspectos econômicos. Inf Agr. 28: 25-42.

Companhia Nacional de Abastecimento (CONAB). Acompanhamento da safra brasileira de grãos: safra 2004/2005, 2008/09, 2012/2013: <www.conab.gov.br/ Conabweb/download/pdf>. 24 mar. 2016.

Cordeiro LAM, Vilela L, Kluthcouski J, Marchão RL (2015) Integração lavoura-pecuária-floresta: $\mathrm{O}$ produtor pergunta, a Embrapa responde. 01. Ed. Brasília-DF: Embrapa, 393p.

Debiasi H, Franchini JC (2012) Atributos físicos do solo e produtividade da soja em sistema de integração lavourapecuária com braquiária e soja. Ci Rur. 42: 1180-1186.

Federação Brasileira de Plantio Direto na Palha (FEBRAPDP.). Evolução do plantio direto no Brasil. <www.febrapdp.org.br/port/html>. 12 mar. 2016.

Flores JPC, Anghinoni I, Cassol LC, Carvalho PCF, Leite JGDB, Fraga TI (2007) Atributos físicos do solo e rendimento de soja em sistema plantio direto em Integração Lavoura-Pecuária com diferentes pressões de pastejo. R Bras Ci Sol. 31: 771-780.

Galford GL, Soares Filho B, Cerri CEP (2013) Prospects for land-use sustainability on the agricultural frontier of the Brazilian Amazon. Philos Trans - R Soc. 111: 1559115596.

Garcia CMP, Andreotti M, Tarsitano MAA, Teixeira Filho MCM, Lima ALS, Buzetti S (2012) Análise econômica da produtividade de grãos de milho consorciado com forrageiras dos gêneros Brachiaria e Panicum em sistema plantio direto. R Cer. 59: 157-163.

Gimenes MJ, Dal Pogetto MHFA, Prado EP, Christovam RF, Costa SAI, Souza EFC (2011) Interferência de Brachiaria ruziziensis sobre plantas daninhas em sistema de consórcio com milho. Sem Ci Agr. 32: 931-938.

Herrero MM, Thornton PK, Notenbaert AM, Wood S, Msangi S, Freeman HA, Bossio D, Dixon J, Peters M, Van De Steeg J, Lynam J, Parthasarathy Rao P, Macmillan S, Gerard B, Mcdermott J, Seré C, Rosegrant M (2010) Smart investments in sustainable food production: revisiting mixed crop-livestock systems. Sci. 327: 822-825.

IPCC - Intergovernmental Panel On Climate Change. Climate change 2014: Synthesis Report: Summary for Policymakers. <www.ipcc.ch>. 18 mar. 2016.

Kluthcouski J, Pacheco AP, Teixeira SM, Oliveira ET (1991) Renovação de pastagem do cerrado com arroz. 1- Sistema Barreirão. Goiânia-GO: EMBRAPA-CNPAF (Documentos, 33), 20p.

Kluthcouski J, Fancelli AL, Dourado-Neto D, Ribeiro CM, Ferraro LA (2000) Manejo do solo e o rendimento de soja, milho, feijão e arroz em semeadura direta. Sci Agric. 57: 97-104.

Kluthcouski J, Aidar H (2003) Implantação, condução e resultados obtidos com o sistema Santa Fé. In: Kluthcouski J, Stone LF, Aidar H (Ed.). Integração lavoura - pecuária. Santo Antônio de Goiás: Embrapa Arroz e Feijão, p.407441.

Krutzmann A, Cecato U, Silva PA, Tormena CA, Iwamoto BS, Martins EM (2013) Palhadas de gramíneas tropicais e 
rendimento da soja no sistema de integração lavourapecuária. Bios Jour. 29: 842-851.

Loss A, Pereira MG, Giácomo SG, Perin A, Anjos LHC (2011) Agregação, carbono e nitrogênio em agregados do solo sob plantio direto com integração lavoura-pecuária. Pesq Agr Bras. 46: 1269-1276.

Loss A, Pereira MG, Perin A, Anjos LHC (2012) Carbon and nitrogen content and stock in no-tillage and crop-livestock integration systems in the cerrado of Goias state, Brazil. J Agric Sci. 4: 96-105.

Loss A, Pereira MG, Torres JLR (2016) Carbono orgânico no solo sob sistemas conservacionistas no Cerrado. In: Amaral Sobrinho NMB, Chagas CI, Zonta E (Org.). Impactos ambientais provenientes da produção agrícola: experiências argentinas e brasileiras. $1^{\text {a }}$ ed.São Paulo: Rio de Janeiro: Livre Expressão, 1: 259-282.

Macedo MCM, Zimmer AH (2007) Sistemas integrados de lavoura-pecuária na região dos cerrados do Brasil. In: Simpósio internacional em integração lavoura-pecuária, 2007, Curitiba. Anais... Curitiba: UFPR, UFRGS, Ohio State University, 2007. (CD-ROM).

Macedo MCM (2009) Integração lavoura-pecuária: o estado da arte e inovações tecnológicas. R Bras Zoot. 28: 133146.

Maia SMF, Ogle SM, Cerri CC, Cerri CEP (2010) Changes in soil organic carbon storage under different agricultural management systems in the south west Amazon region of Brazil. Soi Til Res. 106: 177-184.

Mantovani EC, Pereira FTF, Pereira Filho IA, Viana JHM, Alburquerque Filho MR, Alvarenga RC, Cruz JC (2015) Manejo de solos. In: Cultivo do milho. Sistema de produção 1. Embrapa Milho e Sorgo. 9a edição. 2015. Disponível em: <https://www.spo.cnptia.embrapa.br/temaspublicados>. Acesso: 18 abr. 2016.

MAPA - Ministério da Agricultura, Pecuária e Abastecimento. 2011. Programa agricultura de baixo carbono. 〈www.agricultura.gov.br/abc〉. 12 mar. 2016.

Marchão RL, Balbino LC, Silva EM, Santos Junior JDG, Sá MAC, Vilela L, Becquer T (2007) Qualidade física de um Latossolo Vermelho sob sistemas de integração lavourapecuária no cerrado. P Agr Bras. 42: 873-882.

Mendonça VZ, Mello LMN, Pereira FCBL, Cesarin AL, Yanoet EH (2014) Desempenho agronômico da soja em sucessão ao consórcio de milho com forrageiras no cerrado. R Agr. 7: 26-33.

Moreira WH, Tormena CA, Betioli Junior E, Petean LP, Alves SJ (2014) Influência da altura de pastejo de azevém e aveia em atributos físicos de um Latossolo Vermelho distroférrico, após sete anos sob integração lavourapecuária. R Bras Ci Sol. 38: 1315-1326.

Sales LEO, Carneiro MAC, Severiano EC, Oliveira GC, Ferreira MM (2010) Qualidade física de Neossolo Quartzarênico submetido diferentes sistemas de uso agrícola. Ci Agr. 34: 667-674.

Salton JC, Mielniczuk J, Bayer C, Boeni M, Conceição PC, Fabricio AC, Macedo MCM, Broch DL (2008) Agregação e estabilidade de agregados do solo em sistema agropecuário em MS. R Bras Ci Sol. 32: 11-21.
Salton JC, Mercante FM, Tomazi M, Zanatta JA, Concenço G, Silva WM, Retore M (2014) Integrated crop-livestock system in tropical Brazil: toward a sustainable production system. Agr Eco Env. 190: 70-79.

Santos HP, Fontaneli RS, Spera ST, Tomm GO (2009) Efeito de sistemas de produção integração lavoura-pecuária (ILP) sobre a fertilidade do solo em plantio direto. Act Sci. 31: 719-727.

Santos HP, Fontaneli RS, Spera ST, Maldaner GL (2013) Rendimento de grãos de soja em diferentes sistemas de produção integração lavoura-pecuária. $\mathrm{R}$ Bras Ci Agr. 8: 49-56.

Silva VJ, Camargo R, Wendling B, Pires SC (2011) Integração lavoura-pecuária sob sistema de plantio direto no cerrado brasileiro. Enc Bio. 7: 1-12.

Souza ED, Costa SEVGA, Anghinoni I, Carvalho PCF, Andrigueti M, Cao E (2009) Estoques de carbono orgânico e de nitrogênio no solo em sistema de integração lavourapecuária em plantio direto, submetido a intensidades de pastejo. R Bras Ci Sol. 33: 1829-1836.

Viana MCM, Silva EA, Gontijo Neto MM, Alvarenga RC, Botelho W (2007) Integração Lavoura-Pecuária. In: Interação solo-planta-animal no sistema integração lavourapecuária. Inf Agr. 28: 104-111.

Vilela L, Martha Junior GB, Macedo MCM, Marchão RL, Guimarães Júnior R, Pulrolnik K, Maciel GA (2011) Sistemas de integração lavoura-pecuária na região do cerrado. P Agr Bras. 46: 1127-1138.

Vilela L, Marchão RL, Wruck FJ, Oliveira P, Pedreira BC, Cordeiro LAM (2015) Práticas e manejo de sistemas de integração lavoura-pecuária na safra e safrinha para as regiões centro-oeste e sudeste. In: Cordeiro LAM, Vilela L, Kluthcouski J, Marchão RL (Ed.). Integração lavourapecuária-floresta: o produtor pergunta, a Embrapa responde. DF: Embrapa, 2015. p.103-119. (Coleção 500 Perguntas, 500 Respostas). 